\title{
The 'externalisation' of local public service delivery: experience in Italy and Sweden
}

\section{Daniela Argento and Giuseppe Grossi*}

Department of Business and Social Studies, University of Siena, Piazza San Francesco, 8, 53100 Sienna, Italy

Fax: +390577232641

E-mail: argento@unisi.it

E-mail: grossi@unisi.it

*Corresponding author

\section{Torbjörn Tagesson and Sven-Olof Collin}

\author{
Halmstad University, \\ P.O. Box 823, SE-301 18 Halmstad, Sweden \\ Fax: +46 35157564 \\ E-mail: torbjorn.tagesson@hh.se \\ E-mail: sven-olof.collin@e.hkr.se
}

\begin{abstract}
In recent years, the local government sector in European countries has undergone important changes involving, among other things, the externalisation of local public service provision through various forms of corporatisation, public-public collaboration, public-private partnerships and contracting out. An important consequence of these institutional changes has been the recasting of local governance systems through the need for increased cooperation between public and private actors. This article addresses these matters with comparative reference to the experience in Italy and Sweden. In doing so, it considers local governments in their constitutional and legal contexts, leading to more detailed discussions of their externalisation initiatives and resultant organisational forms and governance arrangements. Issues of ownership have been important concerning the significance of 'community' and 'place' in the management of public affairs.
\end{abstract}

Keywords: externalisation; corporatisation; local public service provision; institutional change; Italy; Sweden.

Reference to this paper should be made as follows: Argento, D., Grossi, G., Tagesson, T. and Collin, S-O. (2010) 'The 'externalisation' of local public service delivery: experience in Italy and Sweden', Int. J. Public Policy, Vol. 5, No. 1, pp.41-56.

Biographical notes: Daniela Argento received her $\mathrm{PhD}$ in Public Management and Regulated Sector at the University of Siena, Italy and currently holds a Research Grant at the Department of Business and Social Studies of the same University. Her research interests include governance and accounting issues of local utilities and organisational change. 
Giuseppe Grossi has a PhD in Business Administration and has been an Associate Professor in Public Management and Accounting at the University of Siena since 2002. He was a Lecturer in Business Administration at the University of Viterbo from 2000 to 2002 . He is a member of the scientific board of the journal Azienda Pubblica and has been a Referee for several international journals. He has authored a number of books and papers and consults on public sector management, management control, public budgeting and reporting.

Torbjörn Tagesson has a $\mathrm{PhD}$ in Business Administration from Lund University and until recently, has been a Senior Lecturer in Accounting at Kristianstad University College. Since 2003, he has been a member of the Swedish Council for Municipal Accounting. From mid 2008, his engagements have been divided between a new position at the Department of Business and Engineering at Halmstad University and the post of Executive Director at the Swedish Council for Municipal Accounting. He is the author of several books and articles on accounting and public administration and is a frequently engaged as a Consultant and Lecturer.

Sven-Olof Collin has been a Professor of Corporate Governance at Kristianstad University College and in mid 2008 is moving to a similar position at Halmstad University. He received his $\mathrm{PhD}$ in Business Administration in 1990. He has published in the areas of corporate governance, public management, gender, methodology and business ethics, dealing with empirical phenomena such as business groups, public-private partnerships, municipal corporations, voluntary labour and riding schools. His current research interests focus mainly on the influence of corporate governance on business development, auditing and accounting choices.

\section{Introduction}

Over the last two decades, many countries have been engaged with managerial reforms inspired by new public management (NPM). These reforms have spread private sector managerial tools and principles to both central and local governments, with the objective of obtaining greater levels of effectiveness, efficiency and economy in the public sector (Hood, 1995; Hughes, 2003; London, 2002). Along with managerial reforms, there have also been institutional reforms aimed at reducing the role of central government in the economic field through the devolution of power and responsibilities to decentralised levels of government, as well as through various forms of privatisation.

The changes introduced have related not only to the internal restructuring of central administrative systems and organisations but also to the processes and procedures for the provision of local public services (Dexia, 2004; Torres and Pina, 2002). Local governments in various countries have gradually abandoned direct forms of management in favour of more indirect forms involving the adoption of various 'externalisation' arrangements, including corporatisation, public-public collaboration, public-private collaboration and privatisation. These externalised forms of management have comprised, respectively, the transformation of units within local governments into semi-autonomous organisations with (mostly) their own private law legal status and with considerable managerial freedom; inter-municipal arrangements of joint service delivery, 
along with the establishment of contractual or institutional public-private-partnerships (PPPs), contracting-out and the delegation of service delivery power to private for profit and non-profit organisations and the total transfer of ownership and/or certain functions and services to private companies (Reichard, 2006; Walsh, 1995; Wettenhall, 2001).

In all cases, there have been important issues of ownership concerning the significance of 'community' and 'place' in the management of public affairs. New institutional solutions have been created for the provision of local public services, resulting in the diversification of organisational forms and ownership structures (Wettenhall, 2003). As a result, internal departments of local governments have needed to collaborate and compete with an array of public and private organisations. On one hand, with more frequent externalisation of public service provision, local governments have taken on a different role. They have needed to find proper means to regulate and control the activities carried out by the different types of external local public service providers in order to combine managerial interests with political responsibility aimed at protecting the customers (Riccaboni, 2003). On the other hand, this trend has also resulted in complex networks which require proper forms of coordination and cooperation between the various stakeholders involved. Thus, local governments have had to establish network relationships with other actors as bearers of distinct interests - sometimes through regulation and control, other times as a partner, and still other times to help facilitate the social and economic growth of an area in order to resolve common problems and to achieve desired results (Kickert et al., 1997; Goldsmith and Eggers, 2004; Grossi and Mussari, 2004).

The erosion of traditional state authority, the devolution of power and responsibility to decentralised levels of government, the introduction of managerialism and competition, and the externalisation of public service provision have all contributed to the transformation of the relationships found among local governments, public service providers and the users of local services (Denters and Rose, 2005). The resulting increased need for interaction among stakeholders has made the boundaries between the public and private sectors hazier, producing a significant variation in systems of local public governance (Rhodes, 2000; Reichard, 2006; Kettl, 2000).

The institutional changes that have occurred make it interesting to investigate the transformation of public service provision and, in the process, to include cross-country comparisons in order to understand similarities and differences (Osborne and Brown, 2005; Pettigrew et al., 2001). In this regard, although international trends like globalisation and economic integration have stimulated countries to make some common choices, variations in receptivity, pace and types of change have been found (Hood, 1995; Lapsley and Pettigrew, 1994). The changes have demonstrated different paths depending on the historical, institutional, political and cultural contexts of each country (Wollmann, 2003; Pollitt and Bouckaert, 2004; Lüder, 2002).

This article contributes to this research topic. It addresses the institutional changes of local public service delivery by comparing the situation in two continental European countries: Italy and Sweden. It seeks to analyse how institutional variants of service provision have developed over time in these two countries. A comparative analysis between Italy and Sweden is interesting because their local governments have a similar multipurpose focus and enjoy some legal independence from the state. The tendency to give more autonomy to municipal companies is also similar in both countries. At the same time, there are differences in their local governments regarding, for example, the 
constitutional and legal frameworks, the degrees of operational autonomy and the implementation of NPM.

The key objective of this article is to describe and explain developments in local public service provision in Italy and Sweden, with a particular interest in corporatisation trends and impacts on local governance. Using empirical data, the article examines these matters in order to identify similarities and differences between the local government systems of the two countries. The analysis is based on secondary data from statistical sources of the countries' official statistical offices, associations of municipalities and municipal organisations.

The article addresses the following research questions. What have been the drivers behind the observed trends of externalisation, especially corporatisation, in the two countries? Which variants of public and private law organisations can be observed in their local governments? Why are municipalities opting for private-law types of organisations? What are the main effects of corporatisation on local governance? What are the main similarities and differences between the relevant experiences of the two countries?

Hereafter, the experience in Italy is examined first, followed by the experience in Sweden. For both countries, the focus is on local government systems and legal frameworks, the institutional landscape, the organisational forms and ownership structures of local public service providers, and the governance issues concerning municipal companies. A comparative analysis of these matters serves to identify some similarities and differences in the processes and results of institutional change, leading to some concluding remarks and suggestion for future research.

\section{Italian experience}

\subsection{Levels of government and legal framework}

Italy historically has had a unitary system of government which in recent years has tended towards a quasi-federal system (Groppi, 2004). The country has four levels of government: the central government, 20 regional governments, 103 provincial governments, and some 8,100 municipalities. Each level has jurisdiction over several issues and activities. Provinces and municipalities are usually referred to as the 'local governments'. Municipalities are responsible for the delivery of services such as water, waste disposal, local public transport, local road maintenance, child education, services for the disabled, elderly and children, municipal policing, building planning and control, recreational services, libraries and cemeteries. Provinces are responsible particularly for transport services, environmental protection and control, supervision of fishing and hunting activities, rural and urban planning, professional education and high school building maintenance (Vesperini, 1999; Rolla, 2002). There are more than 400,000 employees at the local government level: in the municipalities around 362,000 and in the provinces around 42,000 .

The legal framework in the field of local public service provision is complex and continuously changing (Argento, 2008). Local governments must consider European Union legislation (normally incorporated in Italian legislation), national 'horizontal legislation' (local government act, civil code), national sector laws (energy, water, waste, 
transportation) and regional sector laws (after constitutional reform in 2001). Since the introduction of the Financial Act of 2004, a distinction has been made between 'services of economic relevance' and 'services without economic relevance' - in line with the orientation expressed in 2003 in the Green Paper on Public Services by the European Commission.

'Services of economic relevance' have to be managed by companies regulated by private law (joint stock companies and limited companies). Three distinct arrangements are allowed: a company with public, private or mixed public and private ownership identified through public tender (that has to respect national and European Community norms on competition); a mixed public and private company in which the private partner is chosen through a public tender (that also has to respect national and European Community norms on competition); and a company totally owned by a local government (on the conditions that the local government owner exercises over the company an 'analogous control' to what is exercised over its own services and that the company carries out the main part of its activity within the territory of the local government that owns it.

For 'services without economic relevance', the legislation, although recognising the regulations for individual sectors, appears to be more flexible. It gives a local government the possibility of choice within the following management alternatives: direct management by the local government because of the modest sizes or other special characteristics of the services involved; direct assignment to institutions, special undertakings and consortiums, or companies totally owned by the local government; and, in the case of cultural and recreational services, direct assignment to associations or foundations made up of, or participated in by, the local government.

The national legal framework is characterised by uncertainty as a result of continuous discussions on local public service delivery. Currently, the main debated issue concerns restricting the use of direct management and mixed ownership companies for the management of services with economic relevance in order to support the competitive selection of service providers through public tender.

\subsection{Variants in the externalisation of local public service provision}

There have been various externalisation initiatives in local public service provision, including corporatisation, collaborative arrangements, PPPs and contracting-out. Forms of privatisation other than contracting-out have not been widespread at the local level.

With regard to corporatisation, municipalities (depending on their size) directly and indirectly own numerous companies. The larger cities, in particular, have direct control over a series of municipal companies, many of which date back many years and are concerned with various services: energy, water, waste disposal, public transport and cultural services (Grossi, 2007).

Collaborative arrangements have become an issue in recent years. Local governments and their utilities have decided on mergers, resulting in the establishment of consortiums or other forms of joint ventures. The traditional and most widespread form, especially in small and medium local governments, is the inter-municipal association ('consorzio'), to which member municipalities devolve the management of public services (such as waste disposal, transport and social services) and internal services (such as administrative and accountancy services) (Bobbio, 2005). 
PPPs are one of the latest institutional trends at the local level. Approximately $25 \%$ of municipalities are already involved in 'territorial pacts' in the form of agreements between local governments and private associations aimed at improving the economy at the local level. Nearly $30 \%$ of all municipal companies are institutional PPPs: that is, they are companies with a mix of private and public owners, especially in the energy and water sectors (Confservizi, 2006). Private shareholders are generally major national or international groups, but sometimes are also local small- and medium-sized business firms and even private individuals (Grossi, 2007).

The contracting-out of local public services to private companies and non-profit organisations has increased considerably in recent years. Municipalities have contracted-out either whole service packages or significant parts of them to private-commercial and voluntary providers (Padovani, 2004; Cepiku, 2006; Dipartimento della Funzione Pubblica, 2006; Mussari, 2006). Contracting-out has been particularly important in the field of social and cultural services but has also been relevant for internal services such as building maintenance, IT services, administrative services, catering services and office cleaning.

\subsection{Organisational forms of local public service providers}

To carry out their activities, local governments, in addition to direct service provision through internal units, have created companies and use an array of other entities in which they participate totally or partially. Basic details on the various organisational forms are provided in Table 1.

Table 1 Organisational forms of local public service providers

\begin{tabular}{lcc}
\hline Organisational form & Numbers & Percentage \\
\hline Institution & 16 & 1.43 \\
Special undertaking & 185 & 16.54 \\
Consortium & 11 & 0.98 \\
Foundation* & 16 & 1.43 \\
Association* & 15 & 1.34 \\
Cooperative* & 32 & 2.86 \\
Limited company* & 193 & 17.26 \\
Stock company* & 650 & 58.13 \\
\hline
\end{tabular}

Note: *Private law legal status

Source: Confservizi (2006)

An institution ('istituzione') is an organisation which is owned by a local government, without its own legal status. Even if it has managerial and accounting autonomy, it is financially dependent on local government grants. Institutions are usually created in order to provide social and cultural services (libraries, museums, theatres, concerts and the maintenance of historical buildings). 
A special undertaking ('azienda speciale') is an organisation which is owned by a local government and which, unlike an institution, has its own legal status. Even if it, too, has managerial and accounting autonomy, it is also financially dependent on local government grants. Special undertakings have usually been created in order to provide economic services (public transport, public car parks, management of assets) and public works (water services, waste collection and disposal, road maintenance, parks and gardens). Many are currently being transformed into joint stock companies.

A consortium ('consorzio') is owned by more than one local government. Apart from this difference, it has the same organisational structure as a special undertaking and provides the same kinds of services in a broader territorial area.

Foundations ('fondazione') and associations ('associazione') are regulated by private law and are owned either totally or partially by local governments. They are often financially dependent on local government grants. They are formed to provide cultural and social services.

A cooperative ('cooperativa') is a private law regulated organisation owned by several persons who are motivated to collaborate for solidarity and mutual reasons. Cooperatives are especially formed to manage social, cultural and leisure services.

A limited company ('società a responsabilità limitata - srl') can have a majority public or private shareholding and is regulated by private law. Limited companies provide the same services as joint stock companies (addressed below). The limited company form is only available for small-scale enterprises with a minimum equity of 10,000 Euro, which cannot be divided into shares to be traded on the stock exchange.

A joint stock company ('società per azioni - spa') can also have a majority public or private shareholding and is regulated by private law. Joint stock companies are supposed to be financially independent; but, in many cases, the local government owners have to cover their losses. They are usually created to provide economic services, but are sometimes also used for public works and town planning and development activities, as well as for the provision of cultural and social services (social work, shelters for the homeless, home care, elderly care, care of disabled people, social rehabilitation). The joint stock company is considered to be more attractive than other organisational forms as it offers more flexibility and an easy access to the capital markets through the stock exchange.

Joint stock companies and limited companies are now dominating the organisational landscape. Their number more than doubled in just five years: from 405 in 2001 to 843 in 2006 (Confservizi, 2006). They constitute a considerable transformation from public law organisations to private law organisations in corporatised form (Grossi and Mussari, 2004; Valotti, 2006).

Of the joint stock companies and limited companies used in local public service provision, the majority are totally owned by local governments. Few of the joint stock companies have a private majority shareholding, unlike the limited companies whose private majority shareholding is increasing (Confservizi, 2006; Valotti, 2006).

\subsection{Governance issues concerning municipal companies}

Relationships between local governments and the various joint stock and limited companies used are regulated by service contracts. The municipality is at the same time purchaser, local regulator and shareholder, which may cause conflicts of interest. This 
applies not only to the companies which are totally owned by local governments, but also to the mixed ownership companies, including those which are listed on the stock exchange. The problem of interest conflicts is especially strong in the water, waste and transportation sectors, because in those sectors no strong national authorities exist and the municipalities are the only real regulators.

The governance of joint stock companies is regulated by private commercial law (civil code - 'codice civile'). In the case of companies owned by municipalities, the local government act must also be considered. Normally, public companies providing local public services use the traditional model of corporate governance, involving the shareholders' meeting, board of directors, executive committee (not often), president and/or chief executive officer (CEO) and board of auditors.

The shareholders' meeting is really only meaningful when a company is owned by more than one local government or has mixed public-private ownership. The meeting is formed by the mayors of the municipalities which are the owners of the company, along with other owners in the case of a mixed ownership company. The meeting approves (or does not approve) the annual report of the company (but seldom the budget). Sometimes, the shareholders approve 'strategic documents' for the company, which the directors must respect in managing the company. The board of directors is an independent body in managing the company. Shareholders cannot directly interfere in the management of the company. Directors are nominated by the mayor or mayors by a personal decree and are appointed by the shareholders' meeting, which decides the number of directors and their remuneration (Grossi, 2007). In some cases, local government representation on the board of directors is exactly proportional to a local government's participation in the equity of the company. In other cases, it can be more than proportional, with a local government having the right to appoint the majority of directors without holding the majority of the shares. The term of office for directors is three years. Internal financial control of a company is guaranteed by the board of auditors, appointed by the shareholders' meeting and consisting of independent personalities.

A municipal council does not participate in the management of a company. It decides only on the creation of new companies, on possible mergers and on liquidation. Mayors and members of the mayoral cabinet cannot be appointed to the boards of directors. Conflicts of interest are regulated by the commercial law (civil code). In the case of companies listed on the stock exchange, shareholders must respect a specific self-regulation code (the so-called Preda Code) in appointing the directors (Grossi, 2007). In the case of companies owned by two or more local governments, relationships between the shareholders are regulated by specific 'shareholder agreements'; and in the case of companies with a mix of public and private ownership, the relationships are regulated by 'agreements between partners'. These agreements include methods for appointing the boards of directors, the company presidents and/or CEOs and the boards of auditors. The statutes of the company define the majority shareholding necessary to approve the balance sheet and other extraordinary decisions (such as liquidation) in the shareholders' meeting. In the case of companies $100 \%$ publicly owned, the municipalities involved must, according to European law, exercise over the companies a control which is similar to that which they exercise over their own departments; and, at the same time, the companies must carry out the main parts of their activities within the territories of the municipal owners. In practice, it is often difficult for municipalities to observe the 'analogous control' requirement. This has become a problematic issue for local governments. 


\section{Swedish experience}

\subsection{Levels of government and legal framework}

The public sector in Sweden is organised into two main levels: central and local. The local level is further divided into two different administrative systems: county councils ('landsting') and municipalities ('kommuner'). There are 21 county councils. The county councils' primary responsibility is healthcare, but they also deal with public transportation, culture and tourism. The number of inhabitants in a county council area varies between 50,000 and 1.5 million. The 290 municipalities are responsible for local public issues in the immediate environment of citizens, such as pre-school activity, primary and secondary schools, care of the elderly and roads, water and sewerage. The average number of inhabitants in a municipality is 30,000 ; however, the numbers vary considerably. The largest municipality has approximately 760,000 inhabitants while the smallest has fewer than 2,600.

There are more than a million employees at the local government level with approximately 880,000 in municipalities and 250,000 in county councils. Additionally, 75,000 people work in organisations owned by municipalities. In total, the local government sector consumes about $20 \%$ of the GNP (13\% in municipalities and $7 \%$ in county councils) (for more detailed analyses, see Mattisson et al., 2003; SCB, 2007a).

From a legal perspective, the municipalities have to consider European Union legislation (normally incorporated into Swedish legislation), national 'horizontal legislation' (local government act, companies' act) and national sector laws (such as those concerning elderly care, schools, roads). Even though geographical area and compulsory tasks differ, the same basic legislative framework in administrative matters is applicable to both municipalities and county councils. These bodies have large powers of self-determination. They have the right to levy their own taxes and are by law and tradition relatively autonomous from the central government. Their autonomy is prescribed in the Municipality Act ('Kommunallagen') which, among other things, deals with issues concerning legal competence, organisational structures and budgeting.

According to the Municipality Act, the municipalities and county councils can decide on local matters for two different purposes: general and specific. Most local government activities (approximately $75 \%$ of the expenditures) take place within the framework of specific legislation. The legislation is explicit for each field of activity (elderly care, schools, roads), irrespective of whether a municipality undertakes the activity through direct management or through a semi-independent organisation. The legislation stipulates the municipal obligations and the rights of inhabitants.

If there is no specific legislation, municipalities have general authority to decide on 'issues of general public interest', with the direction and level of activity being determined by each municipality independently. In exercising this general authority, municipalities and their associated organisations have to consider the provisions in the Municipality Act, including the key principles: the 'cost price principle', meaning that there is a prohibition on making a profit (with some exceptions in specific legislation concerning, for example, electricity production); the 'equality principle' which holds that municipalities must treat all citizens equally unless there is an objective reason for doing otherwise; and the 'publicly open principle' that all documents are open to be read by everyone. In addition, municipalities and their organisations are not allowed to support individual persons or private companies. 


\subsection{Variants in the externalisation of local public service provision}

The externalisation initiatives in the provision of local public services have been extensive and diverse, just as they have been in Italy. They have included committee and corporate arrangements, along with collaborative ventures, PPPs, contracting-out and other forms of privatisation.

County councils and municipalities are relatively autonomous with respect to the direction and organisation of local activities. Depending on the needs that are perceived, a local government can appoint a number of committees to deal with various tasks. The role of the committees is to carry out the decisions made by a local council. Activities can also be organised and carried out through municipal companies. A council appoints the members of the companies' boards. The number and names of the committees and companies vary considerably, depending on the municipality in each case.

Local public-public collaboration has long occurred in various forms. Over the last few years, there has been an increase in cooperation between municipalities. There are mainly three regulated forms of cooperation: joint committees, municipal federations and companies (most commonly joint stock companies).

PPPs are frequent at the local level (Collin, 1998). They tend to be used for activities concerning industrial policy, tourism and the building and rebuilding of sports centres (Sveriges Kommuner och Landsting, 2005a).

The contracting-out of local public service provision to private organisations does exist, but is still quite limited, with waste collection and public transportation being the main services involved. Essentially as another form of privatisation while the municipalities are responsible for providing education, parents are allowed to choose a private school for their children. The municipalities are then obliged to compensate the private school according to a stipulated tariff.

\subsection{Organisational forms of local public service providers}

Since the introduction of a new and more flexible Municipality Act in 1991, the municipal sector has been characterised by intensive experimentation with different organisational models and market reforms being adopted. Hence, from an organisational point of view, the situation in the local government sector has changed. While previously known as a rather homogenous sector with only minor differences in organisational structure, the sector is now characterised by a variety of organisational forms and local adjustments (Mattisson et al., 2003). Basic details, other than for internal units responsible for the direct provision of services, are presented in Table 2.

Joint committees ('gemensam nämnd') are committees formed by two or more municipalities. A joint committee is responsible for carrying out a specific activity in all of the municipalities that are affiliated members. While each committee has to be associated with a municipality with immediate responsibility for the activity, all affiliated municipalities are represented on the committee. The relationship between the municipalities involved is regulated by a written agreement.

Municipal federations ('kommunalförbund') are organisations owned by more than one local government. A municipal federation is a legal form of public activity regulated by the Municipality Act. Municipal federations are legal entities with direct accountability to the public. 
Table 2 Organisational forms of local public service providers

\begin{tabular}{lcc}
\hline Organisational form & Numbers & Percentage \\
\hline Joint committee & 50 & 3.01 \\
Municipal federations & 91 & 5.49 \\
Partnership and limited partnership company* & 45 & 2.71 \\
Limited company* & 1,363 & 82.22 \\
Economic association* & 17 & 1.34 \\
Non-profit association* & 6 & 0.36 \\
Foundation* & 87 & 5.24 \\
\hline
\end{tabular}

Note: * private law legal status

Partnership and limited partnership companies ('handelsbolag och kommanditbolag') have their own legal status and are regulated by private law. One or all of the municipal and other owners are responsible for all economic obligations of the companies.

A limited company ('aktiebolag') is regulated by private law and can have a public or private majority shareholding. The minimum equity is SEK 100,000 (approximately 10,700 Euro). Limited companies are supposed to be financially independent, but in many cases the public owner will cover any losses. This legal form of business activity is the most commonly used, besides direct service provision. It has been used by municipalities since the end of the 19th century (Collin and Hansson, 1991).

An economic association ('ekonomisk förening') is a legal entity whose members' financial responsibility is limited to their contribution to the entity. Unlike limited companies, there is no formal demand on minimum equity. All members have equal voting rights.

The legal conditions of a non-profit association ('ideella föreningar') are very similar to those of economic associations. The main difference is that non-profit associations are not supposed primarily to undertake economic activities.

Unlike a limited company and economic association, a foundation is a legal entity with no owners or members. It is a proprietor with its own means. It is governed by its charter of foundation and led by a board or foundation manager.

Publicly owned entities are engaged in various policy sectors, with electricity, gas, water, waste disposal, public transport and housing being the most frequent areas of corporate activity. According to the Swedish Association of Local Authorities and Regions, joint committees exist within most municipalities (Sveriges Kommuner och Landsting, 2005b). The number of municipal federations has increased over the last few years, with their main activity being the running of fire brigades. As shown in Table 2, the limited company is the most common organisational form of business activity used by municipalities. Even though limited companies are used for a variety of activities, there is dominance within certain sectors: for example, there are 107 companies responsible for steam power and water supply, and 97 companies are involved in energy distribution (SCB, 2007b). Among the 290 municipalities, a majority (281) has at least one wholly owned company and 288 own at least $10 \%$ of a limited company (SCB, 2007a). None of the municipal companies is listed on any stock exchange. 


\subsection{Governance issues concerning municipal companies}

Most of the municipal companies which manage local public services are wholly owned by municipalities. The relationships between the municipalities and the companies are regulated by law. If a municipality does not own a majority of the shares in a company, it is not allowed to purchase goods or services from the company unless the company has competed for and won the relevant public procurement opportunity. In some sectors such as water, waste and electricity distribution, pricing is regulated by special legislation.

The governance of limited companies is regulated by the Companies' Act. In the case of companies owned by municipalities, local government legislation must also be considered. This can sometimes create conflicts, as the company and local government laws are based on different presumptions.

The governance of the companies is generally in keeping with that described above for Italian companies. Significant arrangements involve the shareholders' meetings, the boards of directors, the CEOs and the auditors, along with a right of the owners to issue written directives that can regulate the companies in more detail than the companies' charters. According to Swedish legislation, a CEO is not allowed to be a member of the board of directors. Shareholders cannot directly interfere in the management of a company, but they can appoint and dismiss the board of directors and, if they are not satisfied with the board, they can hold a special shareholders' meeting to address the matter (Collin, 2001).

\section{Comparative analysis}

In Italy, activities are assigned to local governments consisting of provinces and municipalities, while in Sweden the local governments are represented by county councils and municipalities. Both the Italian and the Swedish local governments have to consider European Union legislation, national 'horizontal legislation' and specific sector national legislation. In Italy, laws enacted by the regions have also to be observed by municipalities and provinces, consistent with the four levels of government.

The legal framework for local governments in Italy has not been as stable over time as that in Sweden. During the last two decades, the regulation of local public service provision has been changed several times. Currently, a distinction is made between the management of local services of economic relevance (energy, water, waste disposal, public transport) and the management of local services without economic relevance (esp. theatres, museums). The arrangements for the provision of services of economic relevance are the subject of particular concern and debate. At the national government level, because of European Commission pressures, there is support for restricting both direct management and mixed ownership management in favour of the competitive selection of public and private providers through public tender.

In Sweden, since the reforms of the 1980s and early 1990s, legislation has sought to protect citizens and users through the principles of cost price, equality and public openness. Compliance with the legislation, however, has not always been satisfactory (Tagesson, 2007; Falkman and Tagesson, 2008). In response, legislative measures have been introduced in an attempt to increase compliance; but they have not been adequate in addressing the matter. Political self-interests, in combination with the lack of sanctions, are important factors that explain the insufficient compliance. There are no sanctions for 
municipalities that violate the legislation, as the legislation does not have any connection to the penal code.

In both countries, local governments have some autonomy from upper levels of government. Italian municipalities obtained more autonomy from central government with the constitutional reform of 2001, while the new Swedish Municipality Act of 1991 increased the self-determination powers of municipalities and county councils. These increases in autonomy have allowed local governments in both countries to diversify the ways in which they provide local public services. Thus, the institutional landscape now includes not only traditional internal units responsible for the direct management of services, but also an array of externalised arrangements involving corporatisation, PPPs and contracting-out.

While municipalities in Italy and Sweden are engaged in several PPPs, there are differences in the sectors in which PPPs are active. In Italy, mixed public-private companies as PPPs have been formed especially in the utility sector (water, electricity, gas, waste disposal), whereas in Sweden PPPs are commonly used in activities concerning industrial policy, tourism and the building of sports centres.

There are also differences in the use of contracting-out arrangements involving private firms and non-profit organisations. Italian municipalities have increasingly contracted-out social services, as well as internal services such as building maintenance, IT services, administrative services, catering services and office cleaning. In Sweden, the contracting-out of local public services is more limited and mostly concerns waste collection and public transportation.

Particularly for small and medium-sized local governments in both countries, inter-municipal cooperation has become a common solution to the need to deliver better services by obtaining economies of scale. This has resulted in various collaborative alliances and ventures forged by two or more local governments with a common interest in the effective delivery of area-wide services.

Most notably, local governments in both Italy and Sweden have favoured the extensive use of corporatised entities in company form as appropriate means of managing a range of local activities. The companies are generally similar in their governance arrangements but differ in terms of their ownership structures. In Italy, they are normally joint stock companies, which can be and often are traded on the stock exchange. In Sweden, while they can and do have both public and private shareholders, none of them is listed on any stock exchange.

The proliferation of various types of organisations providing public services has changed local governance systems. Italian and Swedish municipalities have to interact with several actors because they are responsible for the services rendered to the customers. While in Italy the relationships between the municipality and the entity in charge of services delivery are regulated by specific 'service contracts' and have to respect national, regional and sector legislation, in Sweden those relationships are regulated only by law because no special service contracts are needed. The tendency to delegate the management of public services to external (totally or partially owned) organisations implies that municipalities have to develop adequate regulatory and controlling capabilities (Riccaboni, 2003). This means that the improvement of local governance mechanisms is crucial for both countries in order to guarantee the development of more efficient and competitive public service sectors without losing the primary focus on the public interest. 


\section{Concluding comments}

With the objective of providing better quality services to citizens in a more competitive environment, Italian and Swedish local governments have been involved in various forms of externalisation. The common and most significant trend has been the creation of totally or partially owned organisations in company form. The choice of opting for an externalised, private law form of organisation, especially to manage services of economic significance (electricity, gas, water, waste disposal and public transport), has been driven by the need to create more business-like organisations with degrees of autonomy from local governments. In essence, externalisation through corporatisation has been stimulated by reformative pressures in accordance with the idea that areas of organisational activity will resemble other areas that face the same set of environmental conditions, as affected by various political, economic, social and cultural factors (DiMaggio and Powell, 1983).

All in all, evidence from the two countries demonstrates that externalisation initiatives have changed considerably local public service provision arrangements, modifying local governance systems. The variety of institutional solutions and the peculiarities of specific public service sectors have intensified relations and interdependencies among various actors (Grossi and Mussari, 2004; Reichard, 2006). Local governments now exercise their authority by cooperating or competing with an array of public and private providers and, in the process, need to cope appropriately with various potentially conflicting situations (Kickert et al., 1997; Goldsmith and Eggers, 2004).

This general picture of the landscapes of Italian and Swedish local public service provision offers fertile ground for conducting further and more in-depth research. Given the changes in local governance, it would be especially interesting to investigate in more detail how interaction among local governments and the various service providers and other stakeholders occurs in order to achieve commonly desired results in the public interest.

Most of the arrangements discussed in this article have been motivated by the search for greater efficiency in public service provision, with the effect being to dilute rather than eliminate public ownership. Such further research as suggested here might well consider whether the general citizenry has been happy with the fact that the price for the assumed increase in efficiency has been greater distance between the civic institutions themselves and the providers of local public services.

\section{References}

Argento, D. (2008) Il dominio del cambiamento nella governance del servizio idrico: una comparazione fra Italia e Paesi Bassi, Cedam, Padova.

Bobbio, L. (2005) 'Italy after the storm', in Denters, B. and Rose, L.E. (Eds.): Comparing Local Governance: Trends and Developments, Palgrave, New York, pp.29-46.

Cepiku, D. (2006) L'esternalizzazione Nelle Amministrazioni Pubbliche. Teorie, Politiche ed Esperienze a Livello Internazionale, Aracne, Roma.

Collin, S-O. (1998) 'In the twilight zone - a survey of public private partnerships in Sweden', Public Productivity \& Management Review, No. 21, pp.272-283. 
Collin, S-O. (2001) Ägarstrategier för Kommunens Aktiebolag - En Studie av Praxis 2000 (translated as: Ownership Strategies for Municipal Corporations), Svenska Kommunförbundet, Stockholm.

Collin, S-O. and Hansson, L. (1991) Kommunala Bolag (translated as: Municipal Corporations), Kommunförbundet, Stockholm.

Confservizi (2006) Annuario Associate 2006 - Le gestioni del sistema Confservizi, Roma.

Denters, B. and Rose, L.E. (Eds.) (2005) Comparing Local Governance: Trends and Developments, Palgrave Macmillan, New York.

Dexia (2004) Local Public Companies in the 25 Countries of the European Union, Paris.

DiMaggio, P.J. and Powell, W.W. (1983) 'The iron cage revisited: institutional isomorphism and collective rationality in organisational fields', American Sociological Review, Vol. 48, No. 2, pp.147-160.

Dipartimento della Funzione Pubblica (2006) L'esternalizzazione Strategica Nelle Amministrazioni Pubbliche, Rubbettino, Roma.

Falkman, P. and Tagesson, T. (2008) 'Accrual accounting does not necessarily mean accrual accounting: factors that counteract compliance with accounting standards in Swedish municipal accounting', Scandinavian Journal of Management, Vol. 24, No. 3, pp.271-283.

Goldsmith, S. and Eggers, W.D. (2004) Governing by Network. The New Shape of the Public Sector, The Brookings Institution, Washington.

Groppi, T. (2004) Il Federalismo, LaTerza, Bari.

Grossi, G. (2007) 'Governance of public-private corporations in the provision of local utilities in the Italian case', International Public Management Review, Vol. 8, No.1, pp.130-151.

Grossi, G. and Mussari, R. (2004) 'Governance of institutional and economic relationship: the case of Italian local governments', paper presented at the Eighth International Research Symposium on Public Management, Budapest, 31 March-2 April 2004.

Hood, C. (1995) 'The New Public Management in the 1980s: variations on a theme', Accounting, Organisations and Society, Vol. 20, No. 2-3, pp.93-109.

Hughes, O.E. (2003) Public Management and Administration. An Introduction, 3rd ed., Palgrave Macmillan, New York.

Kettl, D.F. (2000) The Global Public Management Revolution: A Report on the Transformation of Governance, Brookings, Washington.

Kickert, W.J.M., Klijn, E.H. and Koppenjan, J.F.M. (Eds.) (1997) Managing Complex Networks: Strategies for the Public Sector, Sage, London.

Lapsley, I. and Pettigrew, A. (1994) 'Meeting the challenge: accounting for change', Financial Accountability \& Management, Vol. 10, No. 2, pp.79-92.

London, R. (2002) 'Tools for governing: privatization, public-private partnerships and entrepreneurial management', Public Administration Review, Vol. 62, No. 1, pp.118-123.

Lüder, K. (2002) 'Research in comparative governmental accounting over the last decade achievements and problems', in Montesinos, V. and Vela, J.M. (Eds.): Innovations in Governmental Accounting, Kluwer Academic Publishers, Dordrecht, pp.1-21.

Mattisson, O., Paulsson, G. and Tagesson, T. (2003) 'Chapter 8: Sweden', in Lüder, K. and Jones, R. (Eds.): Reforming Governmental Accounting and Budgeting in Europe, Fachverlag Moderne Wirtschaft, Frankfurt.

Mussari, R. (2006) 'Accountability and reporting: new developments in Italian local governments', in Reichard, C., Mussari, R. and Kupke, S. (Eds.): The Governance of Services of General Interest Between State, Market and Society, Wissenschaftlicher Verlag, Berlin, pp.13-33.

Osborne, S.P. and Brown, K. (2005) Managing Change and Innovation in Public Service Organisations, Routledge, London.

Padovani, E. (2004) Il Governo Dei Servizi Pubblici Locali in Outsourcing. Il Controllo Dell'efficacia, Giappichelli, Milano. 
Pettigrew, A.M., Woodman, R.W. and Cameron, K.S. (2001) 'Studying organisational change and development: challenges for future research', Academy of Management Journal, Vol. 44, No. 4, pp.697-713.

Pollitt, C. and Bouckaert, G. (2004) Public Management Reform: A Comparative Analysis, 2nd ed., Oxford University Press, Oxford.

Reichard, C. (2006) 'Strengthening competitiveness of local public service providers in Germany', International Review of Administrative Sciences, Vol. 72, No. 4, pp.473-492.

Rhodes, R.A.W. (2000) 'Governance and public administration', in Pierre, J. (Ed.): Debating Governance, Oxford University Press, Oxford, pp.54-90.

Riccaboni, A. (2003) 'Interessi pubblici e privati nel settore idrico: Le attività di pianificazione e controllo', in Riccaboni, A. (Ed.): Acqua: Fra Incidenza Sociale ed Efficienza Gestionale, Il Ponte Editore, Firenze, pp.323-353.

Rolla, G. (2002) Diritto Regionale e Degli Enti Locali, Giuffrè, Milano.

SCB (2007a) Offentlig Ekonomi 2007 (translated as: Public Sector Finances), Statistiska Centralbyrån (Statistics Sweden), Stockholm.

SCB (2007b) Offentligt Ägda Företag 2006 (translated as: Publicly Owned Enterprises, 2006) Serie Offentlig ekonomi - OE27SM0601, Statistiska Centralbyrån (Statistics Sweden), Stockholm.

Sveriges Kommuner och Landsting (2005a) Offentligt - Privat Partnerskap (translated as: Public Private Partnership), Sveriges Kommuner och Landsting, Stockholm.

Sveriges Kommuner och Landsting (2005b) Available at http://www.skl.se/artikel.asp?C=4312\&A=17231 (accessed on 25 February 2008).

Tagesson, T. (2007) 'Does legislation or form of association influence the harmonization of accounting? - A study of the Swedish water and sewage sector', Utilities Policy, Vol. 15, No. 4, pp.248-260.

Torres, L. and Pina, V. (2002) 'Changes in public service delivery in the EU countries', Public Money \& Management, Vol. 22, No. 4, pp.41-48.

Valotti, G. (2006) 'I nuovi modelli di corporate governance delle imprese pubbliche locali', in Elefanti, M. (Ed.): Evoluzione Delle Imprese Pubbliche Locali, Il Mulino, Bologna, pp.95-143.

Vesperini, G. (1999) I Poteri Locali, Rubbettino, Catanzaro.

Walsh, K. (1995) Public Services and Market Mechanisms: Competition, Contracting and the New Public Management, Macmillan, London.

Wettenhall, R. (2001) 'Public or private? Public corporations, companies and the decline of the middle ground', Public Organization Review: A Global Journal, Vol. 1, No. 1, pp.17-40.

Wettenhall, R. (2003) 'Exploring types of public sector organizations: past exercises and current issues', Public Organization Review: A Global Journal, Vol. 3, No. 3, pp.219-245.

Wollmann, H. (2003) 'Local government reforms in Great Britain, Sweden, Germany and France: between multi-function and single-purpose organisations', Local Government Studies, Vol. 30, No. 4, pp.639-665. 